\title{
Meanings Assigned by Puerperal Women to Episiotomy
}

\begin{abstract}
Antonia Lívia Rodrigues Sousa ${ }^{1}$, Ana Maria Martins Pereira², Maiza Claudia Vilela Hipólito ${ }^{3}$, Valéria Aparecida Masson ${ }^{4}$, Ana Carine Arruda Rolim ${ }^{5}$, Herla Maria Furtado Jorge ${ }^{6}$, José Iran Oliveira das Chagas Junior?, Laura Pinto Torres de Melo 8 Amanda Soares ${ }^{9}$, Lia Maristela da Silva Jacob ${ }^{10}$, Cláudia Jeane Lopes Pimenta ${ }^{11}$
\end{abstract}

\section{Abstract}

Objective: Identify the knowledge and perception of puerperal mothers after completion of routine episiotomy.

Method: This is a descriptive and qualitative study conducted with 13 puerperal mothers in a public hospital in Fortaleza/CE in the month of November 2011, using a previously elaborated interview script. Data were analyzed according to thematic analysis, giving rise to the following category: "Knowledge and perception of puerperal women regarding the episiotomy".

Result: Most women were young, at reproductive phase, outside the formal labor market and ended up going through obstetric interventions without questioning their realization, and only half of the women in the study claimed to have received information about the procedure. The information provided by healthcare professionals on episiotomy conferred greater confidence to mothers. However, only few patients received knowledge in this way.

Conclusion: Knowledge about episiotomy is important for women, enabling them to express their freedom of opinion to comply or reject its realization.

Keywords

Puerperium; Episiotomy; Vaginal Birth; Nursing.
1 Specialist in Obstetrical Nursing, State University of Ceará. Specialist in Family Health, NUTEDS/UFC. Assistance nurse. Granja*

2 Master in Public Health. Professor at the Nursing Undergraduate Program, Faculty Earth Northeast. Assistance nurse at the Center of Normal Birth. Maracanau*

3 Master student of the Faculty of Physical Education of the State University of Campinas. Professor at the National Service of Commercial Training, Campinas**.

$4 \mathrm{PhD}$ in nursing. Coordinator of the Nursing Program of the American Faculty. Professor at the Nursing Course of the Faculty of Jaguariúna and the University of Sao Paulo. Campinas**

5 Master in Public Health. PhD student of the Postgraduate Program in Public Health, State University of Campinas**

6 PhD student of the Postgraduate Program of Obstetrics and Gynecology, State University of Campinas**. Professor at the Nursing Undergraduate Program, University of Fortaleza*

7 Master in Public Health. Professor at the Nursing Undergraduate Program, Faculty Earth Northeast. Technical Assistant of the Department of Health of Ceará State. Fortaleza*.

$8 \mathrm{PhD}$ student of the Postgraduate Program in Clinical Care in Nursing and Health,

State University of Ceará. Fortaleza*.

9 Regional University of Cariri/Decentralized Unit of Iguatu*

10 Specialist in Obstetrical Nursing, School of Public Health of Ceará. Master of Public Health, University of Fortaleza. Ph.D. in Health Sciences from the Nursing School at the State University of Campinas, Campinas, São Paulo, Brazil.

11 Bachelor of Nursing, Federal University of Campina Grande. Cajazeiras, Paraiba, Brazil.

*Ceará, Brazil. **Sao Paulo, Brazil.

\section{Contact information:}

Cláudia Jeane Lopes Pimenta.

झ claudinhajeane8@hotmail.com 


\section{Introduction}

The practice of episiotomy was incorporated into the routine delivery care at the beginning of the last century, with the intention of reducing the damage caused by natural laceration of the perineum, reducing the risk of subsequent urinary and fecal incontinence, and protecting the neonate from birth trauma [1]. A study in Norway found that obstetric anal sphincter injuries are the main risk factor for anal incontinence and sexual problems in primiparous women with episiotomy and that, if the procedure is correctly performed, this can prevent obstetric anal sphincter injuries [2].

Episiotomy is not only a procedure that should not be routinely performed, but it is also unnecessary and possibly harmful. Routine episiotomy has been associated with greater blood loss during delivery, perineal pain, increased risk of severe perineal laceration, greater need for stitches and no clearly confirmed benefits to the mother and/ or the baby. Besides that, the benefits of selective episiotomy indicated in special circumstances are much greater than those found in routine episiotomies [3].

Since 1996, the World Health Organization (WHO) has estipulated an episiotomy rate of about $10 \%$ [4]. An study in Vietnam found that episiotomy was performed to a lesser extent in Vietnamese women who give birth in Australia than in Vietnam, where more than $85 \%$ are subjected to the procedure, not observing associations with adverse outcomes [5].

Seeking to ensure proper care during pregnancy, childbirth and postpartum, for both the mother and child, the Program for Humanization of Prenatal and Birth by Decree/GM n $n^{\circ} 569$, of $1^{\text {rst }}$ of June, 2000, was instituted, based on the analysis of specific care needs of pregnant women [6].

This program enables appropriate guidelines for pregnant women, rights and duties carried out by qualified professionals. Regarding this aspect, the professional nurse specialist in obstetrics has a fundamental role in assisting women.

In this sense, a study in Recife/PE carried out with the purpose to check the risk factors of episiotomy in pregnant women who had normal birth found that such a procedure was strongly associated with births attended by physicians of the team, primiparity and instrumental delivery, and it was less common in deliveries attended by nurses [7].

The inclusion of obstetric nurses in the delivery room had fundamental importance for the reconfiguration of the humanization of childbirth, seeking improvements in their action field in order to develop non-invasive technologies of obstetrical nursing care [8].

Thus, the present study aimed to identify the knowledge and perception of puerperal mothers after completion of routine episiotomy.

\section{Method}

This was an exploratory and descriptive study with qualitative approach. According to Patton, [9] qualitative research is in itself a research field interconnected by words, concepts and assumptions that enable to deepen the processes and meanings that are not examined or measured experimentally in terms of quantity, volume, intensity or frequency and focuses on the socially constructed nature of the reality studied.

The study included 12 mothers who remained under observation in rooming in a public maternity hospital in Fortaleza/CE, selected through purposeful sampling. Data were collected during November 2011 using a previously elaborated interview script [10] with sociodemographic data and guiding questions related to the study objectives.

For the reliability of the testimonies, a voice recorder was used and the identification of the interviews was made through numbers from one to 12 according to the order of participation. Data were analyzed according to Thematic Analysis as 
proposed by Bardin [11] which consists in the set of techniques for analysis of communications in order to obtain, through systematic procedures and objectives of description, the content of messages and indicators that allow the inference of knowledge related to the conditions of production/reception of messages.

Interviews were transcribed in full-length and thorough and successive reading was proceeded in order to allow the categorization of the data, from which the following category emerged: "Knowledge and awareness of puerperal women regarding episiotomy."

The research project followed the guidelines of Resolution $n^{\circ} 466 / 12$ [12] of the National Health Council and was approved by the Research Ethics Committee of the State University of Ceará under opinion $n^{\circ} 11224090-9$. All participants agreed to sign the Informed Consent after having received explanations on the objectives and relevance of the research, making clear the right to participate or withdraw from the study at any time; information, protection and custody of the recorded material, ensuring confidentiality and anonymity.

\section{Results}

Among the 12 study participants, threewere up to 18 years old (25\%); six were aged between 19 and 29 years (50\%) and three were aged over 30 years (25\%). It is noteworthy that four were single (33.3\%), one was divorced (8.3\%) and seven had partners (58.4\%) whether husbands, partners under stable union or recent partners. Nine puerperal women were from Fortaleza. A predominant low-income profile was identified; Seven women (58.4\%) were unemployed, financially depending on the partner or the family; two (16.6\%) reported as profession being housewives; and only three (25\%) reported to receive an income.

Regarding level of education, six (50\%) had completed high school; three (25\%) had not completed high school; two (16.6\%) had completed primary school and one (8.4\%) had not completed primary school.

The analysis of the speeches of the participants enabled the development of the category: "Knowledge and awareness of puerperal women regarding the episiotomy".

\section{Knowledge and perception of puerperal women regarding the episiotomy}

The knowledge about episiotomy puerperal women had is important for the fact that this enables them to decide on the acceptance or refusal to perform such procedure, once it is related to their body. When questioned about what they knew about the procedure, six women said they had not received any information about the procedure; four reported to have acquired the information through friends; one acquired knowledge during prenatal and one in the moment of childbirth.

Already... A friend told me.

M8.

My friends who had done prenatal with me, and had had [baby] before.

M10.

When asked on what they understand by "episiotomy", most reported not having received clarification on the procedure during prenatal consultations and that they were only informed of its realization during labor, as explained in the speeches:

No, because with the doctor at the health center was only the consultation, ultrasound, hear the baby's heart. She never told me, no.

When I had my first [daughter] they did not say anything, but here they said, 'Mom, I will make a cut to help move the child's head, but small and then we do stitches'.

M10. 
When it was close, the doctor said he would make a little "cut". They explained that it was for the child come easy.

M4.

When, in the opposite situation, the professional of the prenatal care is able to anticipate desires and eliminate any doubts through open dialogue, the woman demonstrates confidence and security with respect to the team assisting her in the childbirth, being able to facilitate the labor and keeping mentally prepared even for an episiotomy, if necessary:

The doctor who did the prenatal told me to be very relaxed and very calm and that, maybe, it wouldn't be necesserary to do this cut [...]. I was in labor, the baby was almost born, it was just that she said it would be necessary to make a little cut to facilitate. Ah! I was calm, I was expecting!

Due to lack of information, most of the women felt that they had no "passage", that is, vaginal canal without proper dimension for the passage of the baby, as it is expressed in the following lines:

I know it is to open the passage.

M3.

I think it's for the baby come out easier, faster. When one has not enough opening.

To facilitate delivery, I think it is. She was also 'pulled with iron'.

The definition of "episiotomy" in the notion of women is not explicit, "I never heard of it" is the expression that characterizes the perception of this population. However, answers like "it is to enlarge the opening" implicitly show, in a way, the cultural meaning. An important factor related to perineal trauma is observed in the practice of care, with degree of laceration always associated with the extension of the episiotomy held earlier, regardless of the woman being multiparous or nulliparous.

During interviews, the feeling with respect to the procedure were related to pain, which were referred to as "normal":

Normal. What I really wanted was my son to be born. The pain was so great that I really wanted was to get rid of it as soon as possible.

I find it normal, because at the time we're in pain, what I want is the baby to be born at once.

I could have had openness, I wanted to, of course. Bad thing is the person to be cut, but there was no other way but to be cut. Boring!

\section{Discussion}

The episiotomy was observed in over $50 \%$ of women in this study and almost $75 \%$ of the primiparae. The practice of episiotomy has been incorporated into routine obstetric care without base on any work to assess the risks and benefits of such procedure. Notably, controlled studies have shown that this practice actually increases the risk of third- and fourth-degree perineal laceration, risk of infection and hemorrhage and increases the perineal pain and dyspareunia [13].

Based on the data obtained, it was observed that most women are young, in full reproductive phase and outside the formal labor market. Low education hinders the understanding of birth physiology and reduces the likelihood of women be aware of their rights during pregnancy and childbirth. For this reason, they end up suffering obs- 
tetric interventions without even questioning their realization [14].

It stands out in the study that three women had less than six prenatal consultations nine had six or more. Importantly, only one out of the interviewed women had concluded highschool, had gone through one previous episiotomy; and the rest were primiparae, according to the classification [7]. These findings corroborate the study [13] held in Recife/PE where, among the characteristics of the previous to the childbirth associated with episiotomy were their being primiparous women, with absence of vaginal delivery inprevious gestations and associated diseases at birth. The author [15] highlights that among the associated maternal diseases, hypertensive disorders showed greater prevalence, which was significantly associated with episiotomy.

The information, when received with little clarity may bring disadvantages to this woman, since they can be misinterpreted and differ from woman to woman, because it relates to the experience lived for each woman, and the negative sentiment of vaginal childbirth is often perpetuated.

In a study [2] held in Santa Catarina, the reasons for proceeding the episiotomy, according to the opinion of the subjects of the study, showed how women perceive their own bodies as defective, giving the idea that the vagina does not have enough openess for the passage of fetus. We can see a similar perception among the women interviewed in the present study, referring to the concept that they did not have enough 'openess', that is, assigning an insufficient size for the passage of the fetus through the vagina.

The desire of women and the feeling of financial need, of course, is confirmed by studies conducted by some authors $[7,13]$. Somesaid that women suffer from what has already been labeled as "laborfobia" because it is difficult to convince them to give birth by natural means. Thus, socio-cultural factors may influence the choice of women for abdominal deliveryresulting in excessive rates of cesareans [13].
It was possible to verify that the received guidance during prenatal care is at odds with the recommendations of the Ministry of Health, to advocate the disadvantage of practices that inhibit the "safety and well-being", among them the vaginal touch, performed several times by different professionals [3].

The speeches show women's tendency to perpetuate misinformation, as well as a failure in the transmission of knowledge during the prenatal and postnatal. Little is known about what pervades the feeling and thought of these women in their bodies. The decision-making process takes a form of subordination, transfering the responsibility for the decision to healthcare professionals [13].

The feeling of these women is a combination of emotions related to satisfaction with the birth of the baby, and for this, they allow their bodies to be invaded as if it were a normal event. This result is similar to that found in another study [8] in which the authors claim that women are placed as vectors for the passage of an object, the baby, and allow their bodies to be invaded, medicalized and controlled as if it were a normal episode, seeking to achieve the satisfaction of procreation and successful birth.

The speeches of women denote situations of discomfort and distress, which should be considered by health professionals. Episiotomy features, in this context, as a procedure that violates the rights of choice, because the woman is limited to expressing opinions and feelings about the procedure. It is noteworthy that the academic and public policy are of fundamental importance in this regard.

There is evidence of associated pain and perineal trauma However, there was a greater association of this pain with episiotomy. In this context, it is understandable that women who were victims of an episiotomy may have twice as much perineal pain complaints than a group with intact perineum, being also possible to lessen the pain if the woman is guided to exercise practices during parturition [15]. 
With increasing rates of unnecessary episiotomies, it can be considered that this practice is part of the set of obstetric actions and procedures that constitute an obstetric violence, due to the way it is done without, often, any respect for the woman and the ethical precepts.

The WHO [4] declares obstetric violence as a violation of basic fundamental human rights and the right to quality care with holistic approach must be assured to every citizen, meeting all its needs free from judgment, embarrassment and discrimination, respecting his/her physical and mental health as well as the degree of vulnerability of the pregnant woman.

In 2012 a survey called "Research Born in Brazil [16] was conducted with 23,894 women about labor and delivery in public, private and mixed maternity services of 266 medium and large hospitals from 191 municipalities, capital cities and countryside towns. This study also showed, even more markedly, that the procedures related to labor and the baby's birth are increasingly violent, with high and increasing numbers of stimulant medication (36.4\%), episiotomy (53.5\%), mechanical maneuvers to accelerate birth (36.1\%), cesarean sections without justification (52\%), restriction to bed rest (55.7\%), fasting (74.8\%), enema (91.7\%) and artificial amniotomy (39.1\%).

In face of the testimonies, the fragility of the information provided by professionals during prenatal care and labor became clear. In many situations, the woman lives a condition of dependency and even violence due lack of information. The sharing of information between health professionals and women, at the right time and in a personalized manner, provides the satisfaction of the need for knowledge that expresses and adds power to them, that is, strengthens the ability of pregnant women to decide about their bodies and take care of themselves with autonomy [17].

\section{Conclusion}

At the end of this study we found that the knowledge of puerperal women with respect to episiotomy is limited and controversial. Obstetric interventions are, therefore, frequently performed without questions about their realization. Knowledge of postpartum women about the procedure becomes important for them to feel free to support or deny its realization. Moreover, when the information comes from a health care professional confers confidence to women.

The feeling of these women after the procedure takes a combination of satisfaction with the birth of the baby and a process of subordination to the decision-making act, transferring the responsibility of deciding, without questioning, to health professionals. It is necessary that the multidisciplinary team, especially the nurse, because this is the professional that has more contact with the woman, focus more consistently on actions for further the clarification offered to the patient.

It is hoped that this study may contribute for a reflection on the humanization of obstetric care. Moreover, we believed that nursing, with a key role in the construction of a new scenario of women's health in the country, will become more effective as a vehicle of information.

\section{References}

1. Leal MC, Pereira APE, Domingues RMSM, Theme Filha MM, Dias $M A B$, Nakamura-Pereira $M$ et al. Obstetric interventions during labor and childbirth in Brazilian low-risk women. Cad. Saúde Pública [Internet], Rio de Janeiro, 2014 Aug; 30(suppl. 1): S1747. DOI: http://dx.doi.org/10.1590/0102-311X00151513

2. Stedenfeldt M, Pirhonen J, Blix E, Wilsgaard T, Vonen B, Øian P. Anal incontinence, urinary incontinence and sexual problems in primiparous women - a comparison between women with episiotomy only and women with episiotomy and obstetric anal sphincter injury. BMC Womens Health [Internet], 2014; 14(157): 2-7. DOI: 10.1186/s12905-014-0157-y

3. Carroli G, Mignini L. Episiotomy for vaginal birth. The Cochrane Collaboration [Internet]. 2009; Issue 1. DOI: 10.1002/14651858. CD000081. 
4. Organização Mundial de Saúde (OMS). Assistência ao parto normal: um guia prático. Brasília (DF); 1996.

5. Trinh AT, Khambalia A, Ampt A, Morris JM, Roberts CL. Episiotomy rate in Vietnamese-born women in Australia: support for a change in obstetric practice in Viet Nam. Bull World Health Organ [Internet], 2013 May; 91(5):350-6. DOI: 10.2471/BLT.12.114314

6. Ministério da Saúde (BR). Secretaria de políticas públicas de saúde. Parto aborto e puerpério: Assistência humanizada à mulher [Internet]. 2. ed. Brasília (DF): MS; 2003. Available from: http://bvsms.saude.gov.br/bvs/publicacoes/cd04_13.pdf

7. Braga GC, Clementino STP, Luz PFN, Scavuzzi A, Noronha Neto C, Amorim MMR. Risk factors for episiotomy: a case-control study. Rev Assoc Med Bras [Internet], São Paulo, 2014 Sept/ Oct; 60(5): 465-72. DOI: http://dx.doi.org/10.1590/18069282.60.05.015

8. Nascimento NM, Progianti JM, Novoa RI, Oliveira TR, Vargens OMC. Tecnologias não invasivas de cuidado no parto realizadas por enfermeiras: a percepção de mulheres. Esc Anna Nery [Internet], Rio de Janeiro, 2010; 14(3): 456-61. DOI: http://dx.doi.org/10.1590/S1414-81452010000300004

9. Patton M.Q. Qualitative evaluation and research methods. Newbury Park, CA. Sage Publications, 1990.

10. Turato ER. Tratado da metodologia da pesquisa clínicoqualitativa: construção teórico-epistemológica, discussão comparada e aplicação nas áreas da saúde e humanas. 5. ed. Petrópolis, RJ: Vozes; 2011.

11. Bardin L. Análise de conteúdo. 3. reimp., 1. ed. São Paulo: Edições 70; 2011.

12. Ministério da Saúde (BR). Diretrizes e normas regulamentadoras de pesquisas em seres humanos. Resolução n. 466 de 12 de dezembro de 2012 [Internet]. Brasília: Ministério da Saúde; 2012. Available from: http://conselho.saude.gov.br/resolucoes/2012/ Reso466.pdf

13. Raisanen S, Vehvilainen-Julkunen K, Gisler M, Hei - nonen S. A population-based register study to de - termine indications for episiotomy in Finland. Int J Gynaecol Obstet [Internet], 2011 Oct; 115(1):26-30. DOI: 10.1016/j.ijgo.2011.05.008

14. Moura, FMJSP et al. A humanização e a assistência de enfermagem ao parto normal. Rev Bras Enferm [Internet], Brasília, 2007 July-Aug; 60(4): 452-5. DOI: http://dx.doi. org/10.1590/S0034-71672007000400018
15. Mathias AERA, Pitangui ACR, Vasconcelos AMA, Silva SS, Rodrigues OS, Dias TG. Mensuração da dor perineal no pósparto vaginal imediato. Rev Dor [online], São Paulo, 2015 OCt/Dec; 16(4): 267-71. DOI: http://dx.doi.org/10.5935/18060013.20150054

16. Biscegli TS, Grio JM, Melles LC, Ribeiro SRMI, Gonsaga RAT. Violência obstétrica: Perfil assistencial de uma maternidade do interior do Estado de São Paulo. Cuid Aarte, Enferm [Internet], 2015 Jan/Feb; 9(1): 18-25. Available from: http://fundacaopadrealbino.org.br/facfipa/ner/ pdf/Revistacuidarteenfermagem\%20v.\%209\%20n.1\%20\%20 jan.\%20jun\%202015.pdf

17. Oliveira DC, Mandu ENT. Women with high-risk pregnancy: experiences and perceptions of needs and care. EsC Anna Nery [Internet], 2015; 19(1): 93-101. DOI: http://dx.doi. org/10.5935/1414-8145.20150013
Publish in International Archives of Medicine

International Archives of Medicine is an open access journal publishing articles encompassing all aspects of medical science and clinical practice. IAM is considered a megajournal with independent sections on all areas of medicine. IAM is a really international journal with authors and board members from all around the world. The journal is widely indexed and classified Q1 in category Medicine. 